\title{
BOOK REVIEW: WOJCICKI, E. (2019). HOW TO RAISE SUCCESSFUL PEOPLE: SIMPLE LESSONS FOR RADICAL RESULTS. BOSTON, NEW YORK: HOUGHTON MIFFLIN HARCOURT
}

\author{
Desislava Cheshmedzhieva-Stoycheva²
}

Following its international premiere on May 1, 2019, the book written by Esther Wojcicki is now available on the Bulgarian market under the title Как да отгледаме успешни личности - 5 принщипа за възпитание на целеустремени деца от „Крьстницата“ на Силициевата долина (literal translation: How to raise successful people - 5 principles how to educate driven children by the "Godmother" of the Silicon Valley) thanks to the Publishing House of Assenevtsi Trade.

Although the book sounds like yet another piece on parenting or like one of the so-called self-help books, it is far from that. The fact that it is written by one of the first women journalists in the US, a teacher with work experience of more than 40 years, and a mother of three successful women, predetermines its value. For those interested in social networks and video sharing platforms the name Wojcicki might sound familiar, as Esther is the mother of Susan Wojcicki, the co-founder of Google and CEO of YouTube. The other two Wojcicki daughters have also managed to find their own path and be successful in male-dominated spheres: Janet Wojcicki is a professor of pediatrics at the University of California-San Francisco, and Anne Wojcicki is founder and CEO of $23 \mathrm{andMe}$, a genetic company which strives to empower patients so they receive transparent information on their health. All three Wojcicki daughters have grown to be the individuals they are today as a result of the way they were brought up and educated.

As Esther herself states, there should be Nobel Prizes on parenting and education as "They are the two most important things we do in our society. How we raise and educate our children determines not only the people they become but the society we create" (Wojcicki, 2019, p. xix). Using her own life and work experience, Esther Wojcicki describes her philosophy of parenting

2. Associate Professor, PhD at Shumen University, Department of English Studies, Shumen, Bulgaria, e-mail: d.stoycheva@shu.bg 
and successful education as built around the development of skills and values defined as TRICK (Trust, Respect, Independence, Collaboration, and Kindness). Esther views these values as fundamental for the development of children able to thrive in this fast and competitive world.

The book is logically built around these five values and each one of them is duly explained and backed up with examples from Esther Wojcicki's personal and professional life. As Wojcicki herself states, the problem of today's education is that it does not allow students to think independently and outside the box. Instead, it postulates that teachers are the "omniscient" authorities who are infallible and right in everything they teach and that children do not have a say in what gets taught in school; both teachers and children follow a curriculum that allows little room for creativity and students simply have to rote learn things they do not fully understand and things they are not interested in. This is one of the major issues Wojcicki tries to provide a working solution for in her book. Using her own experience gained from her classes in Journalism, Grammar and English, Esther Wojcicki shows that teachers can be creative in the ways they teach and at the same time they can gain respect and recognition based on their professionalism, rather than on authority, which is of great importance as the identity of the teacher can influence positively and motivate students' learning ability (see also Ivanova, 2019). Discussing the identity of the teacher further, Wojcicki also states that looking back at one's childhood and analysing the experiences people have gone through as children helps them make sense of some of their individual traits ${ }^{3}$ and at the same time makes them understand better the challenges students face. Thus teachers can relate better to their students and try to see the process of education from their perspective. Wojcicki (2019) is convinced that showing trust, being respectful, innovative, understanding and kind to one's students gains their respect and motivates them to learn and achieve their goals.

Teaching results prove to be higher when students find themselves in a trusting environment where they feel valued as people and when they are interested in the things they $\mathrm{do}^{4}$. As Esther herself states "Whenever kids can be experts in something, they feel good about themselves. They can be experts in Minecraft or in insects or whatever they want. It doesn't matter. They just need to be experts." (Wojcicki, 2019, p. 77). This gives students better self-esteem and they participate actively in their own education. When children find their calling

3. Here Esther Wojcicki closely resembles Maria Montessori's philosophy that the child is the man of tomorrow, or put in a different way, that childhood predetermines one's adulthood. That is why it is very important that children from a very young age should be educated (or prepared) for life but this should happen following their natural processes of growth (see Montessori, 1946).

4. This idea very closely resembles Montessori's who using Herbart's methodology postulates that interest is the factor that "keeps the mind amused [...] plunged in the idea" (Montessori, 2016, p. 34). 
they can develop and prosper. However, if they follow somebody else's dream of what they should be, they do not develop their full potential because they simply do not feel the other person's ideas as their own and they cannot find the necessary motivation ${ }^{5}$.

Furthermore, Wojcicki claims that in order for TRICK to be effective the teachers/ parents should model the values they are trying to promote and teach - a fact supported by research in the field of neuroscience (see Gunn, 2018). Just like a parent preparing her/ his children for life, Esther has been preparing her students for the profession of journalists, giving them enough freedom to make their own educated decisions working on the school newspaper: the students choose their own editors, topics that get published, ways to research the issues at hand, and means to obtain funding, to mention but a few.

In addition, although not defined as such, Wojcicki's philosophy closely resembles the research carried out on social and emotional learning (SEL) in schools which includes "values development, conflict resolution, anger management, self-esteem enhancement, peer mediation, and several classroombased interventions within subject area teaching" (Martin, 2012, p. 1469; see also Weissberg, 2016; Gun, 2018; CASEL, 2019). Moreover, Goleman (n.d.) claims that SEL programs occurred as a "war on..." a particular problem and they "also taught children specific social-emotional skills like self-awareness, self-management, empathy, perspective taking, and cooperation. In short, they were lessons in emotional intelligence" which ultimately help them face the challenges in their lives - the things Esther Wojcicki has managed to achieve through the implementation of the values of TRICK.

Thus, rather than being simply a book on parenting, Esther Wojcicki's How to raise successful people (2019), provides guidance into new and successful methods of education which are not only theoretical but prepare students for real life and develop them as trustworthy, reliable, independent, cooperative and kind individuals.

5. Schunk (2012, p. 346) states that when students are motivated to learn they follow what has been taught in class, linking the new information with the old and finding other ways to complete projects and acquire additional knowledge. "They choose to work on tasks when they are not required to do so; in their spare time they read books on topics of interest, solve problems and puzzles, and work on computer projects. In short, motivation engages students in activities that facilitate learning." (ibid.) and this is what has been observed in Wojcicki's classes on Journalism and during production week when the school journal Campanile is published. 


\section{References:}

CASEL. (n.d.). Retrieved from https://casel.org/about-2/

Goleman, D. (n.d.). Social \& emotional learning. Retrieved from http://www.danielgoleman. info/topics/social-emotional-learning/.

Gunn, J. (2019, June 03). Teaching children empathy using social-emotional learning theory. Retrieved from https://education.cu-portland.edu/blog/classroom-resources/teachingchildren-empathy-sel/

Ivanova, I. (2019). Strengthening teacher identity and professionalism as a way to increase the appeal and status of teaching profession. Studies in Linguistics, Culture, and FLT 5, Sofia: Asenevtsi, 34-48.

Martin, R. A. (2012). Social and Emotional Learning Research: Intervention Studies for Supporting Adolescents in Turkey. Procedia - Social and Behavioral Sciences, 69, 1469-1476. doi: 10.1016/j.sbspro.2012.12.087

Montessori, M. (1946). The absorbent mind. Adyar, Madras, India: The Theological Publishing House.

Montessori, M. (2016). The advanced Montessori method. Vol. I. Amsterdam: MontessoriPearson Publishing Company.

Schunk, D. H. (2012). Learning theories: An educational perspective. $6^{\text {th }}$ ed. Pearson Education Publishing.

Weissberg, R. (2016, February 15). Why social and emotional learning is essential for students. Retrieved from https://www.edutopia.org/blog/why-sel-essential-for-studentsweissberg-durlak-domitrovich-gullotta 